\title{
SALES PERSONS' WORK METHODS INFLUENCE ON CUSTOMER SATISFACTION AND ORGANISATION ACTIVITIES
}

\author{
Katri JAKOSUO \\ Lahti University of Applied Sciences, Finland
}

\begin{abstract}
Service quality ideology emphasises the meaning of good services and the significance of professional personnel. Along with this ideology, the relationship between personnel and customer is one of the most important factors affecting estimations of service quality. The purpose of this paper is to ascertain how personnel work methods influence a customer's satisfaction.
\end{abstract}

The analysis is based on a customer satisfaction survey $(n=40,692)$, and a personnel satisfaction survey $(n=1,507)$ from the year 2000 carried out by Finland Post (today Itella). In this study I compare post offices in which customer satisfaction is particularly high $(n=10)$ and post offices wherein customer satisfaction is particularly low $(n=10)$. The results of the analysis were complemented by interviews with five service experts in spring 2010.

The main finding of the research is that those post offices in which customer satisfaction is particularly high have aimed at certain methods of procedure which are mutually directed at customer satisfaction. Also, target-oriented and dexterous activity, the quality of the supervisor's work, openness and experience of working under a fair amount of pressure are typical of these post offices. In the future, the organisations will be able to improve their procedures by checking that all employees know and understand the organisation's targets and their own job descriptions. It is also important to encourage employees to work together and monitor how employees treat the customers.

Keywords: Customer Satisfaction, Job Satisfaction, Service Innovations, Work Methods

\section{INTRODUCTION}

Ongoing global regression affects an organisation's operational environment. In this situation it is important to monitor costs and take care of customers. Customer service is one area where different organisations can compete and where they can develop a competitive advantage. The service-oriented organisational culture creates higher value and a better result.

The purpose of this paper is to ascertain how personnel work methods influence a customer's satisfaction. The article proceeds in the following manner. First, I briefly review the literature regarding service quality and service innovations. Second, I analyse via quantitative and qualitative data how personnel work methods influence a customer's satisfaction. In the analysis, I compare post offices in which customer satisfaction is particularly high and post offices wherein customer satisfaction is particularly low. Finally, I present the implications and limitations of the research.

\section{LITERATURE REVIEW}

\section{Connections between Job Satisfaction and Customer Service Quality}

The service quality ideology emphasises the meaning of good services and the significance of professional personnel. Along with this quality ideology, the role of the personnel is becoming more signifi-cant. The relationship between the personnel and the customer is one of the most important factors affecting estimations of service quality: In most cases, services are delivered during the interaction 
between customers and employees. Thus employees' attitudes and behaviours towards customers affect how customers perceive service quality and how satisfied they are. Skilled and professional personnel are considered the essential resources and a strategically competitive advantage for organisations. (Buzzell \& Gale 1987; Bowen \& Lawer 1992; Heskett, Jones, Loveman, Sasser \& Schlesinger 1994; Zeithaml, Berry \& Parasuraman 1996; Chance \& Green 2001; Román \& Ruiz 2005.) Some researchers even claim that the personnel are one of the most important resources of any organisation. (Ulrich 1997; Ganesh, Arnold \& Reynolds 2000; Farrell, Souchon \& Durden 2001.) Especially in service sector is the role of the personnel important, because their actions affect customer satisfaction and an organisation's profitability: job satisfaction is the mainstay of customer-oriented behaviour, and satisfied workers provide better service for their customers (Saura, Contrí, Taulet \& Velázquez 2005). Also, it has been observed in Finnish quality research that the personnel significantly affect the way in which customers evaluate the quality of service (Jakosuo 2002; 2005).

Thus managing the customer relationship also means monitoring how employees treat the customers. According Kaplan and Norton (1996; 2001; 2004), without understanding the organisation's vision and strategy, employees cannot adapt their work to contribute to effective strategy implementation.

Like service in general, the quality of service is also quite difficult to describe. Simplistically, we can say that the quality of service is based on the customer's experience, that is, what s/he gets (technical quality) and how s/he experiences the service process (functional quality) (Grönroos 1990; 2009, Jakosuo 2002). Usually customers' evaluations of the quality of service are based on many different factors. During the service process they normally evaluate the quality of interaction, how long they must queue and what kind of premises the organisation has. Further, the organisation's corporate image effects a customer's willingness to use services. This business image is build upon what the customer's experience of the business is. Even though the organisation's top management creates the outward prerequisites, the personnel can affect the outcome of the service process.

The quality of interaction is built upon the customer's experience, which in turn depends on how the personnel behave, what their attitude towards work and customer service is, how willing they are to serve customers and how well they are able to co-operate (Grönroos 1990; 2000; Jakosuo 2002). As we shall see, the quality of interaction is composed of those things which are related to an organisation's culture and the behaviour of its personnel.

The qualities of the physical resources are composed of elements in the service production process and those products that the organisation offers its customers. These resources consist of, for example, goods, the physical environment, machines, business premises, furnishing and clarity of signs. Although the personnel cannot normally affect an organisation's physical resources, they have the responsibility of ensuring the tidiness of the service points (Jakosuo 2002; 2005). Equally, when we consider the availability of a service, the personnel cannot affect what the location of a service with regard to transport facilities will be, but they can affect the length of time the customer must queue.

Previous studies have found that the way the organisation treats employees and puts the emphasis on customers, affects the feelings and attitudes of employees, and their ability to deliver service quality. The service-oriented organisational culture creates higher value and a better result (Saura, Contrí, Taulet \& Velázquez 2005; Little \& Dean 2006).

A supervisor's actions are also significant. The supervisor's actions have a significant influence on the employees' commitment and ability to provide high quality service. The supervisor, who acts as a role model, builds employee self-confidence and enhances employee satisfaction. If the supervisors do have a clear vision, then usually job satisfaction in the work environment and customer satisfaction will be greater (Kantabutra \& Avery 2006; Little \& Dean 2006). Yoon, Seo and Yoon (2004) found that the degree of supervisory support influences the employee's motivation, job satisfaction and performance. They also found that the employees' cognitive appraisals of customers' active participation in the service delivery process have a direct, positive impact on their job satisfaction and service efforts, and this in turn influences the customer's perception of employee service quality.

According Emery and Barker (2007, 93), in successful teams workers have a high degree of responsibility, authority for making day-to-day decisions in areas such as tasks, assignments, training, work methods, quality control and problem solving. Team work has been found to increase job satisfaction and decrease employee turnover. The commitment of the team is important, because it has been 
shown that team commitment translates into a willingness to help co-workers and an increase in job performance. Employees who are committed are also less likely to change employer and require less time-consuming and costly supervision. Allred $(2001,9)$ emphasises that it is very difficult to create high levels of external customer satisfaction without equivalent levels of internal customer satisfaction.

\section{Practices and Procedures as Service Innovations}

The definition of innovation is hard to pin down. Innovation can be an idea, a practice or an object that is perceived as new. Also, an innovation can be an old idea in a new application or exploitation used as a new method of production or product handling. Innovations can incorporate or adopt new technology for improving products, services or/and processes. Innovations can be so-called marketing innovations, which introduce new marketing methods for products, or so-called organisational innovation, which is linked to practices, workplace organisations or external relations. (Orange, Elliman, Kor \& Tassabehji 2007, 244-245.)

According to Lin, Chen and Chiu $(2010,114)$ there are two key aspects of innovation: the degree of innovation and the scope of innovation. The degree of innovation varies from radical innovation to incremental innovation. Radical innovation is a dramatic breakthrough in new areas and incremental innovation modifies current products, services or technology. The scope of innovation capability consists of both technical and administrative innovation. Technical innovations include products, marketing, services and the technology used to produce products, product sales or render services directly related to the basic work activity of an organisation. Administrative innovation is related to organisational structure and administrative processes. These are indirectly related to the basic work activity of the organisation and are more directly related to its management. Snyder and Duarte (2003) emphasises that innovation should create a new, better product or service that offers something valuable for customers and a sustainable competitive advantage for the supplier.

Service sector innovations can relate to different practices and procedures. Den Hertog (2000) proposes five patterns for service innovations. These are 1) supplier-dominated innovation, 2) innovation in services, 3) client-led innovation, 4) innovation through services and 5) paradigmatic innovation. Thus, service sector innovations can fluctuate from environmentally friendly banking services to facility management of commercial centres. According to Allred (2001), for example in Browning Company innovations were linked into the activities. The company improved its activities and profit, that is, organised specific product and service training for employees and developed new procedures which improved customer satisfaction (e.g. all customer orders would be imported directly into the ordering system and all incoming calls would be answered within ten seconds).

Lin, Chen and Chiu $(2010,116)$ emphasise that customer involvement has a positive effect on product, process, administrative and marketing innovations. The organisations which are more customeroriented than their competitors are more capable of understanding and forecasting the changes in future markets.

According to service quality theories and innovation theories, the personnel's work methods influence customer satisfaction quality. One way organisations can increase their competitiveness is by improving the work methods. In this study I shall try to discover if there are any features which are common to those post offices in which customer service quality can be described as quite excellent.

\section{DATA AND METHODS}

Themes typical of personnel surveys are, for example, motivation, professional skills, the physical environment, management, a supervisor's actions and rewarding (Staines \& Quinn 1979; Ang \& Soh 1997; Morrel-Samuel 2002; Rollison \& Broadfield 2002; Hampton \& Hampton 2004). Customer satisfaction surveys usually measure a service point's physical resources, personnel kindness and professional skills, corporate image and waiting times (Parasuraman, Berry \& Zeithaml 1991; Zeithaml, Berry \& Parasuraman 1993; Jakosuo 2002; 2005). These themes were included in Finland Post's customer satisfaction surveys (Service Quality Indicator) and personnel satisfaction surveys (Personnel Inquiry). 
The analyses are based on post office customer feedback and Finland Post's Personnel Inquiry from the year 2000 and interviews from the year 2010. The customer material had been supplemented by post office customer feedback from spring $2000(n=40,692)$, while the personnel material comprised Finland Post's Counter Services personnel research in autumn $2000(n=1,507)$. This study considered of only Finland Post's own post offices, and not other postal agencies. I augmented the results of this analysis by interviewing five service experts in spring 2010. The interviewees represented different fields in the service sector (e.g. management, development and education) and different regions (Uusimaa and Päijät-Häme).

Once a year Finland Post measures how satisfied post office customers are. This survey is called the Service Quality Indicator. By answering this survey, customers can contribute to the development of the Post's services. In the year 2000 all post offices owned by Finland Post and the 300 biggest agencies took part in the survey. The inquiry was based on 12 questions. These questions considered the quality of customer service, such as interaction, the quality of actions and physical resources. By answering this survey, personnel could contribute to the development of their work. In the year 2000 the inquiry was based on 93 questions. These questions considered such areas as work climate, the Post's image as company and employer, leadership and management.

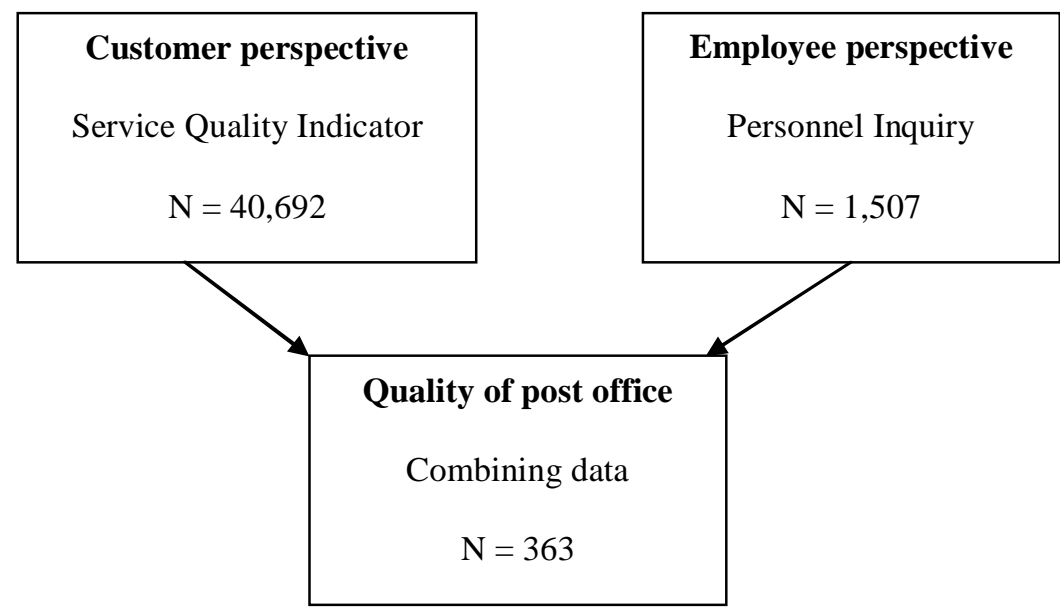

For this research the postal codes taken from the observations were used for connecting the data (Figure 1).

\section{Figure 1. The Combining of Customer Satisfaction Data and Personnel Satisfac- tion Data}

Here I took into account only those post offices for which the results of customer satisfaction surveys and personnel satisfaction surveys were available $(n=363)$ (Table 1). The Personnel Inquiry was based on structured statements on a scale of one to seven $(1=$ totally disagree, $7=$ totally agree and $4=$ nei-

\begin{tabular}{|c|c|c|c|c|c|c|}
\hline \multicolumn{2}{|c|}{ Personnel Inquiry } & \multicolumn{2}{|c|}{ Service Quality Indicator } & \multicolumn{3}{|c|}{ Background questions } \\
\hline $\begin{array}{l}\text { Q1... } \\
\text { (mean) }\end{array}$ & $\begin{array}{l}\ldots . Q 993 \\
\text { (mean) }\end{array}$ & $\begin{array}{l}\text { Q1... } \\
\text { (mean) }\end{array}$ & $\begin{array}{l}\text {..Q12 } \\
\text { (mean) }\end{array}$ & $\begin{array}{l}\text { personnel } \\
\text { (n) }\end{array}$ & $\begin{array}{l}\text { customers } \\
\text { (n) }\end{array}$ & postcode \\
\hline \multicolumn{6}{|c|}{ 1. post office information } & FIN-00100 \\
\hline & . & & . & . & . & . \\
\hline . & . & . & . & . & . & . \\
\hline . & . & . & . & . & . & . \\
\hline \multicolumn{6}{|c|}{ 363. post office information } & FIN-99980 \\
\hline
\end{tabular}


ther agree nor disagree). The Service Quality Indicator measures level of service on the scale: excellent (5), very good (4), good (3), satisfactory (2) and poor (1).

After data connection, I made a sampling based on the offices' customer satisfaction results. First, I calculated the general customer satisfaction index for each post office and then I sampled the ten best and the ten weakest post offices. This grouping was based on a mean which was determined from the Service Quality Indicator's questions 1-11. In this research, I did not take question 12 into consideration because it did not measure the post office's internal activities. In this study I concentrated only on those customer service factors which the post office personnel can influence.

\section{RESULTS}

\section{The Analysis of Quantitative Data}

In Figure 2 it can be seen that in customer satisfaction, the biggest differences were related to the post offices' physical resources (Q7), smoothness of carrying on business (Q10) and swiftness and efficiency of service (Q5). The difference between the best and weakest post offices was the smallest in that question which measured Finland Post's image (Q12). It is noteworthy that in this study those factors which describe the interaction between sales persons, such as the smoothness of doing busi-

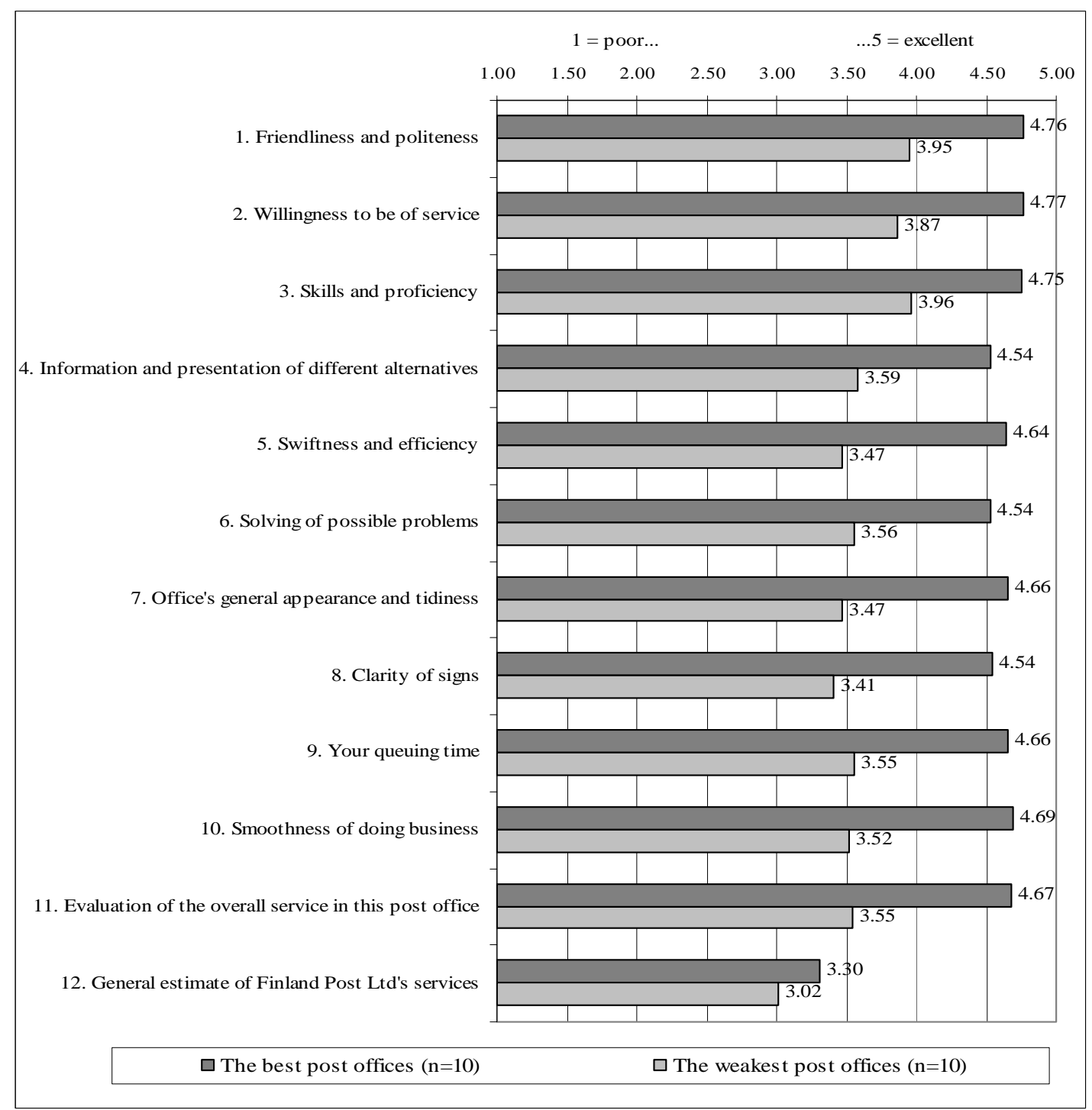

ness and the office's general appearance and tidiness, are high. This result suggests that in the weakest post offices the quality of the individual sales person is quite good, but teamwork between different sales persons needs to be developed. 


\section{Figure 2. Customer Satisfaction: A Comparison between the Best Post Offices and the Weakest Post Offices}

Next, I tried to establish those Personnel Inquiry variables which distinguish the best offices from the weakest. In this analysis, I took into account only those Personnel Inquiry questions in which the differences between different variables were the highest. The selection criteria were the differentials between the best offices' scores and the weakest offices' scores, which must be at least 0.50 .

According to the results, the best post offices' personnel feel that their work unit operates smoothly and the quality of action is good (Table 2). It is interesting that in the best post offices, the personnel critically evaluate those questions which measure the quality of a supervisor's actions and Finland

Table 2. Strengths of the Best Post Offices

\begin{tabular}{|l|l|}
\hline Personnel Inquiry questions & Difference * \\
\hline Q10. Our unit adheres to established methods & 1.08 \\
\hline Q16. Our rewarding promotes initiative and responsible action & 0.98 \\
\hline Q4. The work climate is good & 0.88 \\
\hline Q11. Our methods support Post' targets and are parallel with other units & 0.83 \\
\hline Q46. Amount of work stress is reasonable & 0.81 \\
\hline Q65. We react quickly and flexibly to customers' requirements & 0.77 \\
\hline Q18. Our unit goals support company goals & 0.74 \\
\hline Q13. Our work is focused on reaching our targets & 0.73 \\
\hline Q8. We have a good chance of learning from others' behaviour & 0.70 \\
\hline Q5. We handle disagreements constructively & 0.65 \\
\hline Q64. The quality of work arrangements is good & 0.64 \\
\hline Q9. Different groups can work together while not seeking their own interests & 0.59 \\
\hline Q7. I can easily obtain all the information I need in my work & 0.55 \\
\hline Q89. I know the bases of rewards & 0.54 \\
\hline
\end{tabular}

Post's employer and corporate image. The differences between the best and the weakest post offices are the clearest in those questions which measure the work unit's actions and quality of actions.

* In this table the score differences between the best and weakest post offices have been calculated. For example: the best post offices Q10 (mean 5.70) - the weakest post offices Q10 (mean 4.62) = difference between means is 1.08 .

In the best post offices, the personnel feel that the work climate is good (Q4), rewarding systems promote initiative and responsible action (Q16) and all adhere to established methods (Q10). It is typical that in these post offices employees can easily obtain all the information they need at work (Q7), different groups work together and they do not seek their own interests (Q9), possible conflicts are handled constructively (Q5), and people have a chance to learn from the behaviour of others (Q8). Also, target-oriented and parallel activity is usual in these post offices (Q11 and Q13).

In those questions which measure the quality of activity, respondents are especially satisfied with work arrangements (Q64) and methods through which they can react quickly and flexibly to customer needs (Q65). Why then are the personnel satisfied with their work arrangements? One explanation might be that in the best post offices, the personnel's view is that the amount of work stress is reasonable (Q46). They also understand the bases for rewarding, unlike the personnel in the weakest post offices (Q89).

In Table 3 it can be seen that in the best post offices the personnel evaluate critically those questions which measure the quality of a supervisor's action, and discussion of development (Q40, Q49, Q52, 
Table 3. Weaknesses of the Best Post Offices

\begin{tabular}{|l|l|}
\hline Personnel Inquiry questions & Difference* \\
\hline Q72. Supervisor know my educational and developmental needs & -1.70 \\
\hline Q24. I trust in the Post's future & -1.09 \\
\hline Q40. I have enough information to evaluate performance & -1.03 \\
\hline Q73. The development discussion with my supervisor is useful & -0.77 \\
\hline Q35. The Post's top management respects employees & -0.75 \\
\hline Q23. The Post is a successful company & -0.75 \\
\hline Q56. Supervisor tell us how to obtain our targets & -0.75 \\
\hline Q41. I get acknowledgement and feedback in my work & -0.66 \\
\hline Q53. I get feedback from my superior & -0.61 \\
\hline Q49. I have an open relationship with my superior & -0.59 \\
\hline Q76. My supervisor tells me about and clarifies my targets & -0.54 \\
\hline Q26. The Post is a good place to work & -0.54 \\
\hline Q52. My supervisor gives me acknowledgement & -0.53 \\
\hline
\end{tabular}

Q53, Q56, Q72, Q73 and Q76). In addition, these employees take a critical view of the Post's future (Q24) and statements that Finland Post is a successful company (Q23) and a good place to work (Q26).

* In this table the score differences between the best and weakest post offices have been calculated. For example: the best post offices Q73 (mean 2.92) - the weakest post offices Q73 (mean 4.62) $=$ the difference between means is -1.70 .

These results confirm earlier studies: high customer satisfaction seems related more to a post office's internal quality than to its external quality (Jakosuo 2002). For example, the critical evaluations of Finland Post as an employer do not have a negative influence on customer service quality. High customer satisfaction seems to be more linked to the post office's internal quality of action than to the Post's employer image. It is interesting to bear in mind that in this study the supervisor's actions doe not much influence customer satisfaction quality. One explanation might be found in the construction of the data. Over 90 per cent of Finland Post's salespersons have worked over 11 years for Finland Post. This means that they are professionals who do not need the supervisor's guidance as much as their younger colleagues.

\section{The Analysis of Qualitative Data}

After the qualitative data analysis, I conducted five interviews in which I tried to identify how organisations can improve their procedures. In the interviews my aim was to discover how organisations can help employees to adhere to established methods, how organisations can help employees to learn from others and motivate them to work together without seeking their own interests. I was also interested in their opinions about information and rewarding. These themes were based on the results of the quantitative data.

According to the findings from the interviews, increasing interaction between different employee groups is one way of helping employees to adhere to the established methods. At the work places there are two key aspects of interaction: the degree of interaction and the scope of interaction. It is very important that interaction from the top down functions properly and the organisation culture supports an attitude of receptiveness. If the organisational culture is open and healthy, possible conflicts can be handled constructively together. Successful work units confer together and reach a common, 
shared understanding of what the organisation's targets and processes mean to the unit. It is very difficult to provide a high level and homogeneous customer service without a common, shared view.

Organisations can enhance the way in which employees learn from the behaviour of others so that clear targets and understandable indicators may be established. Also, it is important to encourage employees to continuously improve their service to customers. Learning one another is linked to the employee's motivation and satisfaction. If employees are unmotivated and dissatisfied, they will not usually be prepared to share their know-how. According to the findings from the interviews, organisations can motivate different groups to work together without seeking their own interests, thus setting a clear vision, making clear job descriptions and providing attainable targets. Further, it is important for the monitoring to be continuous and for the organisation culture to reward success.

The interviewees emphasised the important of information. Employees which work on routine tasks do not have much time to read messages and guidelines. Therefore, the length of the text must be short and the content of the message clear and unambiguous. The service sector uses a lot of part-time and temporary employees. These employees do not always understand the operational environment and the organisation's projects catchwords. Hence, it is also good to avoid abbreviations and work slang.

The interviewees also discussed rewarding, which affects employees' job satisfaction and the way in which they treat customers. These interviewees observed that it is important for the reward system to be fair, justifiable and open. It is important for the supervisor to set the targets at the beginning of the year, so that employees will have enough time to reach the targets. Also, it is necessary for the organisation's middle and top management to stand behind these targets and act as a role model. For example, if the supervisors are not interested in monitoring the standard of activity and the results, it is difficult to expect the employees to adhere to these procedures. Two of the interviewees emphasised that the rewarding system must consist of two parts: individual performance and team performance. They said that this model rewards individuals for outstanding results and yet also takes into account those employees who have their own important role in common projects, although they do not belong the group of top sales people. One of the interviewees noted that if the reward system is based solely on the supervisor's own opinion about an individual employee, an employee who is not the supervisor's favourite might find it hard to receive a merited increase.

\section{DISCUSSION AND IMPLICATIONS}

The main purpose of this study was to find out how the personnel's work methods are related to customer satisfaction. My qualitative examination is based on two large quantitative research studies: Finland Post's customer satisfaction $(n=40,692)$ and personnel satisfaction surveys $(n=1,507)$ from the year 2000. In this research, I benchmarked post offices wherein customer satisfaction is particularly high $(n=10)$ and post offices in which customer satisfaction is particularly low $(n=10)$. I augmented the results of the analysis by interviewing five service experts in spring 2010.

According to the results, those post offices in which customer satisfaction is particularly high have aimed at certain methods of procedure which are mutually directed at customer satisfaction. Also, target-oriented and dexterous activity, the quality of the supervisor's work, openness and experience of working under a fair amount of pressure are typical of these post offices. This receptiveness showed up especially in conflict and learning situations. In such cases differences of opinion were handled in a constructive way and people had a good chance of learning from the behaviour of others.

In the best post offices, the personnel were satisfied with their working arrangements, and they considered that the workloads are reasonable. In practice, the benefit of a good working arrangement is that the personnel are in less danger of becoming overworked and this means better opportunities to offer a good service to customers.

It was noticeable that in the best post offices, the personnel adhered to established practices and different groups did not seek their own interests. These post offices reacted quickly and flexibly to customer needs, too. One explanation for this finding may be that in the best post offices the personnel were awarded a prize for initiative and responsible action. Also, a target-oriented approach guided the personnel's activities in these post offices. For example, in all the best post offices the personnel knew how their own work unit's targets were related to Finland Post's targets. Target-oriented and parallel action is very important, because it helps to attain Finland Post's targets. 
This finding, related to target-oriented action, supports a view that the personnel's understanding of an organisation's target has a positive effect on its profitability (Kaplan \& Norton 1996; 2001; 2004). In Finland Post's case target-oriented action affected customer satisfaction positively.

Even the best post offices' personnel, who were satisfied with their own work unit, criticised Finland Post as an employer. This result does not support the view of Grönroos $(2000 ; 2009)$ that an organisation's internal climate also reflects an organisation's culture. In this research the personnel felt that the work unit's work climate was good-even then they felt that Finland Post's upper management does not appreciate its employees enough. This result supports the opinion that an organisation's internal and external reputations are connected (Bromley 1993; Young 1996). Also, the findings support the theory that a good work climate improves employees working ability (Robbins 1986).

My empirical findings suggest some important managerial implications. First, I found that it is important to identify the organisation's positive and negative attitudes and procedures and determine how these things affect the organisation's activities. In Finland Post's Counter Services in 2000 positive attitudes were reflected in established methods, responsible action based on rewarding systems, flexible procedures, the chance of learning from others' behaviour and constructive methods to handle disagreements. Lack of information, lack of acknowledgement and undervaluation of employment were examples of negative attitudes.

Another important finding is that in the view of the day-to-day management's it is important that supervisors

- check that all employees know and understand the organisation's vision and targets

- check that all employees know and understand their own job descriptions

- encourage employees to work together

- continuously encourage employees to improve customer service

- reward teams and individuals for success

- monitor how employees treat customers

- act as a role model.

One way to encounter future challenges is to improve the organisation's managerial skills and supervisors' actions. The other way to encounter future challenges is to admit that maybe not all wisdom comes from within the organisation; rather from customers. Customer-oriented organisations see customers as active partners and they are able to utilise the customer's know-how. Customers can, for example, test new procedures and products in authentic situations. Employees can also, for instance, observe and follow customers' actions so that they understand better customers' needs. These processes help organisations to make their action comprehensible to the personnel and focus on the right things. In the service innovation's view these new procedures are incremental innovation, because these procedures modify current services and create higher value for customers (Snyder \& Duarte 2003; Lin, Chen \& Chiu 2010).

\section{LIMITATIONS}

The principal limitations of this study concern four aspects: the scope of the study, the task type, the simplicity of the data and the age of the data. First, this study was carried out in the context of the Finnish postal services, which represent public services. Therefore, there may be several possible problems related to cross-national or cultural research. In addition, the employees represented sales persons, whose tasks consist of routine services. For this reason, the results may vary in non-routine services. Because the data consisted of results from only 20 post offices, these data represent only a small part of the post office network and generalisation from the results is impossible. Finally, the quantitative data is 10 years old and only the qualitative data is new. Therefore, the combination of the quantitative and qualitative data is questionable. On the other hand, according to the interviews, the questions concerning developing work methods and rewarding are still current. 


\section{REFERENCES}

Allred, A. T. (2001), Creating Customer Service Worth Advertising at Browning Arms, The TQM Magazine 13 (1), pp. 6-11.

Ang, J. and Soh, P. H. (1997), User Information Satisfaction, Job Satisfaction and Computer Background. An Exploratory Study, Information and Management, 32 (5), pp. 255-266.

Bowen, D. E. and Lawer, E. E. (1992), The Empowerment of Service Workers: What, Why, How and When, Sloan Management Review, 33 (3), pp. 31-39.

Bromley, D. B. (1993), Reputation, Image and Impression Management, John Wiley and Sons Ltd., New York.

Buzzell, R. D. and Gale, B. T. (1987), The PIMS Principles: Linking Strategy to Performance, The Free Press, New York.

Chance K. G. and Green, C. G. (2001), The Effect of Employee Job Satisfaction on Program Participation Rates in the Virginia WIC-Program, Journal of Public Health Management and Practice, 7 (1), pp. 10-20.

Den Hertog, P. (2000), Knowledge-Intensive Business Services as Co-Producers of Innovation, International Journal of Innovation Management, 4 (4), pp. 491-528.

Emery, C. R. and Barker, K. J. (2007), Effect of Commitment, Job Involvement and Teams on Customer Satisfaction and Profit, Team Performance Management, 13 (3-4), pp. 90-101.

Farrell, A. M., Souchon, A. L. and Durden, G. R. (2001), Service Encounter Conceptualisation: Employees Service Behaviours and Customers' Service Quality Perceptions, Journal of Marketing Management, 17 (5-6), pp. 577-593.

Ganesh, J., Arnold, A. J. and Reynolds, K. E. (2000), Understanding the Customer Base of Service Providers: An Examination of the Differences between Switchers and Stayers, Journal of Marketing, 64 (July), pp. 65-87.

Grönroos, C. (1990), Nyt kilpaillaan palveluilla, Weilin+Göös, Jyväskylä.

Grönroos C. (2000), Service Management and Marketing: A Customer Relationship Management Approach, John Wiley and Sons Inc., Chichester.

Grönroos C. (2009), Palvelujen johtaminen ja markkinointi, WSOYpro Oy, Juva.

Hampton, G. M. and Hampton, D. L. (2004), Relationship of Professionalism: Rewards, Market Orientation and Job Satisfaction among Medical Professionals, Journal of Business Research, 57 (9), pp. 1042-1053.

Heskett, J. L., Jones, T. O., Loveman, G. W., Sasser, E. W. Jr. and Schlesinger, L. A. (1994), Putting the Service-Profit Chain to Work, Harvard Business Review, (March-April), pp. 164-174.

Jakosuo, K. (2002), Hyvä palvelu, huono imago: Tutkimus toimipaikkojen palvelujen laadusta, Suomen Postin tutkimussarja 14/2002, Helsingin yliopiston Taloustieteen laitoksen lisensiaattityö, Edita: Helsinki.

Jakosuo, K. (2005), Asiakas- ja henkilöstötyytyväisyyden väliset yhteydet: Tapaustutkimus Suomen Postista, Suomen Postin tutkimussarja 39/2005, Helsingin yliopiston Taloustieteen laitoksen väitöskirja, Yliopistopaino, Helsinki. 
Kantabutra, S. and Avery, G. C. (2006), Vision Effects in Customer and Staff Satisfaction: An Empirical Investigation, Leadership and Organisation Development Journal, 28 (3), pp. 209-229.

Kaplan, R. S. and Norton, D. P. (1996), The Balanced Scorecard. Harvard Business School Press, Boston, MA.

Kaplan, R. S. and Norton, D. P. (2001), The Strategy-focused organization, Harvard Business School Press, Boston, MA.

Kaplan, R. S. and Norton, D. P. (2004), Strategy Maps, Harvard Business School Press, Boston, MA.

Lin, R.-J., Chen, R.-H. and Chiu, K. K. (2010), Customer Relationship Management and Innovation Capability: An Empirical Study, Industrial Management and Data Systems, 110 (1), pp. 111-133

Little, M. M. and Dean, A. M. (2006), Links between Service Climate, Employee Commitment and Employees' Service Quality Capability, Managing Service Quality, 16 (5), pp. 460-476.

Morrel-Samuel, P. (2002), Getting the Truth into Workplace Surveys, Harvard Business Review (February), pp. 111-118.

Orange, G., Elliman, T., Kor, A. L. and Tassabehji, R. (2007), Local Government and Social or Innovation Value, Transforming Government: People, Process and Policy, 1 (3), pp. 242-254.

Parasuraman, A., Berry, L. L. and Zeithaml, V. A. (1991), Understanding Customers Expectations of Service, Sloan Management Review, (Spring), pp. 39-48.

Robbins, S. P. (1986), Organizational Behaviour: Concepts, Controversies and Applications, 3rd edition, Prentice Hall International, New Jersey.

Rollison, D. and Broadfield, A. (2002), Organisational Behaviour and Analysis: An Integrated Approach, 2nd edition, Prentice Hall, Essex.

Román, S. and Ruiz, S. (2005), Relationship Outcomes of Perceived Ethical Sales Behaviour: The Customer's Perspective, Journal of Business Research (58) 4, pp. 439-445.

Saura, I. G., Contrí, G. B., Taulet, A. C. and Velázquez, B. M. (2005), Relationships Among Customer Orientation, Service Orientation and Job Satisfaction in Financial Services, International Journal of Service Industry Management, 16 (5), pp. 497-525.

Snyder, N. T. and Duarte, D. L. (2003), Strategic Innovation: Embedding Innovation as a Core Competency in Your Organisation, Jossey-Bass, San Francisco.

Staines, G. L. and Quinn, R. P. (1979), American Workers Evaluate the Quality of Their Jobs, Monthly Labor Review, (January), pp. 3-12.

Ulrich, D. (1997), Human Resource Champions: The Next Agenda for Adding Value and Delivering Results, Harvard Business School Press, Boston, MA.

Yoon, M. H., Seo, J. H. and Yoon, T. S. (2004), Effects of Contact Employee Supports on Critical Employee Responses and Customer Service Evaluation, Journal of Services Marketing, 18 (5), pp. $395-412$.

Young, D. (1996), Building Your Company's Good Name. How to Create and Protect the Reputation Your organization Wants and Deserves, Amacom, New York.

Zeithaml, V. A., Berry, L. L. and Parasuraman, A. (1993), The Nature and Determinants of Customer Expectations of Service, Journal of Academic Marketing Science, (Winter), pp. 1-12.

Zeithaml, V. A., Berry, L. L. and Parasuraman, A. (1996), The Behavioural Consequences of Service Quality, Journal of Marketing, 20 (2), pp. 31-46. 